\title{
Effects of honey-bee alarm pheromone compounds on the behaviour of Varroa jacobsoni
}

\author{
B Kraus \\ Institut für Bienenkunde, Polytechnische Gesellschaft, Fachbereich Biologie der JW Goethe- \\ Universität, Karl-von-Frisch-Weg 2, D-6370 Oberursel/Ts, FRG
}

(Received 3 August 1989; accepted 19 January 1990)

\begin{abstract}
Summary - In a simultaneous choice test, bees killed by freezing were more attractive to Varroa than bees stung to death by other bees.

The smell of the sting apparatus proved to be repellent for Varroa. In addition, 6 out of 9 alarm pheromone compounds were significantly repellent. Next to isopentyl-acetate, which showed no effect, 1-octanol is the most quantitatively important alarm pheromone compound of Apis mellifera. With that substance, Varroa showed the strongest repellent effect in both olfaction and chemocontact perception tests. An amount of $0.5 \mu \mathrm{l}$ 1-octanol, present in 1 sting apparatus, injected into dead bees caused significantly more mites to leave these bees after only $30 \mathrm{~s}$ than water injected into control bees. 1-octanol is obviously an important chemical trigger for Varroa to leave a bee which is stung or just contaminated with alarm pheromone during robbing.
\end{abstract}

Apis mellifera / alarm pheromone / repellen / compound / Varroa jacobsoni

\section{INTRODUCTION}

Several honey bee hormones and pheromones influence behaviour or physiology of the bee parasite Varroa. JH (III) in the bee hemolymph is a possible trigger for the mite to start egg laying (Hänel, 1983). Honey bee Nasonov pheromone decreases the attractiveness of foragers for Varroa (Hoppe and Ritter, 1988).

Sakofski (1989) examined robbery as a mechanism for transferring considerable numbers of Varroa from hive to hive. He recovered up to $40 \%$ of the mites from the robbed colony in the colony of the robbing bees. From Sakofski's studies, as well as from our observations, it was apparent that Varroa only rarely changes its host bee. Sakofski found that only $5 \%$ of the mites changed their host bee during $24 \mathrm{~h}$. How- ever, during robbery, the rate of host changing is evidently increased. Sakofski also observed Varroa changing between fighting bees. These observations point to specific stimuli causing the mites to leave their stung host bees. The results of previous experiments with bee extracts indicated that the sting apparatus contains substances repellent for Varroa. In this paper, effects of the sting apparatus and the alarm pheromone compounds on Varroa behaviour were tested.

\section{MATERIALS AND METHODS}

The experiments were performed in 1988 and 1989. The bees (Apis mellifera carnica, Pollmann) were kept in a flight room during winter. Mites were collected from nurse bees directly at the beginning of the test. Only mites positioned under the host's sternites were tested. 
As part of the results, an index is given to signify mite reactions (substance/substance + control). An index of 0 would mean that all the mites prefer the control and that the tested substance is extremely repellent.

\section{Simultaneous choice test between bees killed by freezing and bees stung to death by other bees}

Ten bees from a different colony were added to a cage with 50 bees. The fighting bees were observed until 1 of them was stung. The bee was then frozen whilst still living. The control bees were also killed by freezing. During the tests, the bees were situated at opposite sides of a glass Petri dish (diameter $5 \mathrm{~cm}$ ) with the legs towards the centre where the mite started its run. The position of the mite was scored after 60 $\min$.

\section{Wind channel (Y-maze) test of sting apparatus and sting apparatus alarm pheromone compounds}

Through a Y-glass tube an airstream, with a speed of approximately $1.2 \mathrm{~m} / \mathrm{s}$, was conducted. The outside diameter of the tube was $2 \mathrm{~cm}$, the length of each trail $5 \mathrm{~cm}$. From 1 tube, an airstream without smell, and from the other

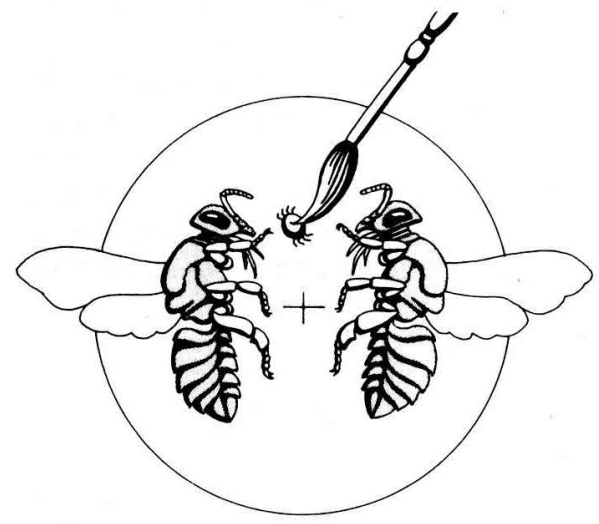

Fig 1. Simultaneous choice test between bees killed by stinging or freezing. tube, an airstream with the smell of the sting apparatus or the tested substance was lead into the starting tube. The airstream was conducted over a paper carrying $5 \mu \mathrm{l}$ of substance or 5 sting apparati. The mite was introduced into the middle of the starting tube through a small entrance hole. The distance between the starting point and the branch point was $3 \mathrm{~cm}$. A decision was scored after $1 \mathrm{~min}$ if the mite had entered the substance tube or the control tube.

\section{Test of alarm pheromone compounds incorporated in wax tubes}

The substance was mixed with beeswax in a concentration of $1.0 \%$. The wax was formed into a tube closed on 1 side, with the length of $3 \mathrm{~cm}$, an outside diameter of $1 \mathrm{~cm}$ and a weight of 0.5 g. Five Varroa were placed inside and it was, then attached to a second tube made from pure wax. After $30 \mathrm{~min}$, the position of the mites was registered. The experiments were conducted at $34^{\circ} \mathrm{C}$.

\section{Injection of 1-octanol into bees}

Nurse bees were killed by freezing. Under the 2nd sternite $0.5 \mu \mathrm{l}$ of the tested pheromone compound was injected with a syringe. The bees were placed into a Petri dish with the injection spot downward to avoid direct contact of the mites with the substance. The treated bee was placed back to back with an untreated target bee. The wings of the bees were removed. Two mites were placed upon the abdomen of the treated bee. The positions of the mites were scored after $30 \mathrm{~s}$ and $30 \mathrm{~min}$. The same test was carried out with control bees which had received an injection of water.

\section{Host changing test}

In 2 wooden cages, 100 Varroa bees marked with color were kept together with 100 bees without Varroa. A Petri dish with $0.2 \mathrm{ml} 1$ octanol was placed under 1 of the cages. After $1 \mathrm{~h}$, the number of mites which had changed to bees without Varroa was registered. 


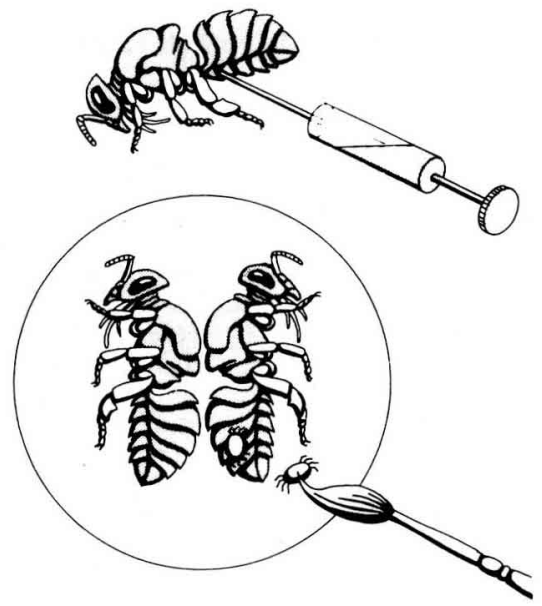

Fig 2. Injection of 1-octanol into bees.

\section{RESULTS}

In the simultaneous choice test between bees killed by freezing and bees stung to death by other bees, we found 57 Varroa on bees stung to death and 119 on bees killed by freezing. Thus, the bees killed by freezing are significantly more attractive than the bees stung to death $\left(\chi^{2}=21.8\right.$, $P<0.001$ ).
In the wind channel (Y-maze) test with the smell of 5 sting apparati (st) on 1 side and a control airstream without smell (c) on the other side, 95 Varroa were found in the control tube and 33 mites in the tube with the smell of sting apparati. Thus, the sting apparatus is repellent at a very high level $\left(\chi^{2}=30.0, P<0.001\right)$. The index st $(s t+c)$ is 0.26 .

The tests with the smell of alarm pheromone compounds (table I) in a wind channel showed the following results : four of the tested substances were repellent at a very high significance level $\left(\chi^{2}=10.83, P\right.$ $<0.001)$. Butyl acetate was repellent at a high significance level $\left(\chi^{2}=8.5, P<0.01\right)$. 2-heptanol was significantly repellent $\left(\chi^{2}=\right.$ $4.8, P<0.05$ ). Three of the tested substances did not show any significantly attractive or repellent effect $\left(\chi^{2}=1.0\right)$.

The tests of alarm pheromone compounds in wax tubes (table II) showed that, with the exception of isopentyl acetate, all the tested substances are clearly repellent $\left(\chi^{2}=10.83, P<0.001\right)$. Isopentyl acetate is neither attractive nor significantly repellent $\left(\chi^{2}=0.3\right)$.

In the test with injection of 1-octanol into bees, the observation of the mites position after $30 \mathrm{~s}$ bee 72 mites were positioned on

Table I. Tests of sting apparatus alarm pheromone compounds in a wind channel. $c=$ control; $s=$ substance.

\begin{tabular}{lcccc}
\hline \multicolumn{1}{c}{ Substance } & $c$ & $s$ & Significance level $\mathrm{P}$ & Index $\mathrm{s} /(\mathrm{s}+\mathrm{c})$ \\
\hline & & & & \\
1-octanol & 27 & 3 & 0.001 & 0.10 \\
2-nonyl acetate & 25 & 5 & 0.001 & 0.17 \\
2-nonanol & 25 & 5 & 0.001 & 0.17 \\
2-methyl butanol & 25 & 5 & 0.001 & 0.17 \\
butyl acetate & 23 & 7 & 0.01 & 0.23 \\
2-heptanol & 42 & 18 & 0.05 & 0.30 \\
hexyl acetate & 55 & 45 & 0.75 & 0.45 \\
isopentyl acetate & 49 & 51 & 0.90 & 0.51 \\
2-hexanol & 48 & 52 & 0.90 & 0.52 \\
\hline
\end{tabular}


Table II. Tests of alarm pheromone compounds in wax tubes. Number of tests per substance $=12$. Mites per test $=5 . c=$ control; $s=$ substance.

\begin{tabular}{lcccc}
\hline \multicolumn{1}{c}{ Substance } & $c$ & $s$ & Significance level P & Index $s /(s+c)$ \\
\hline 1-octanol & 58 & 2 & 0.001 & 0.03 \\
2-heptanol & 57 & 3 & 0.001 & 0.05 \\
2-nonyl acetate & 55 & 5 & 0.001 & 0.08 \\
2-nonanol & 53 & 7 & 0.001 & 0.12 \\
2-methyl butanol & 53 & 7 & 0.001 & 0.12 \\
butyl acetate & 50 & 10 & 0.001 & 0.17 \\
1-hexanol & 49 & 11 & 0.001 & 0.18 \\
hexyl acetate & 46 & 14 & 0.001 & 0.23 \\
isopentyl acetate & 32 & 28 & 0.7 & 0.47 \\
\hline
\end{tabular}

the treated bee, 23 on the untreated, and 5 that left both and after $30 \mathrm{~min}, 29$ mites on the treated bee, 45 on the untreated, and 26 that left both. If the same test is conducted with the injection of water instead of 1-octanol, the positions of mites were as follows : after $30 \mathrm{~s}, 89$ mites on the treated bee, 8 mites on the untreated bee and 3 mites that left both, after 30 min, 65 mites on the treated bee, 33 on the untreated bee and 2 mites that left both.

The difference between the number of mites that left the bees treated with 1octanol and the number of mites that left the bees treated with water, was highly significant $(P<0.01)$ after $30 \mathrm{~s}$. Not all of the mites attached onto the untreated target bee, but rather, left both bees.

The difference in the number of mites that changed from treated bees to untreated bees, in the octanol group and the control (water) group, is also highly significant. The differences after $30 \mathrm{~min}$ are even more pronounced $(P<0.001)$.

In the control group of the host changing test, 75 mites could be found on Varroa bees and 14 on bees originally without Varroa; in the octanol group, 55 mites were found on Varroa bees and 14 mites on bees originally without Varroa. Thus, 1octanol did not cause a significantly more frequent change of mites from 1 bee to another $\left(\chi^{2}=0.6, P<0.5\right)$. A summarizing list of the tested alarm pheromone components and their results in the different tests is given in table III.

Isopentyl acetate (IPA), which is the major constituent of alarm pheromone, is ineffective in both tests. The pheromone compound with the second highest quantity, 1octanol, is the most effective component in both tests. Spearman's rank correlation between the wax tube tests and the wind channel tests is highly significant $\left(r_{s}=\right.$ $0.77, P<0.01$ ).

\section{DISCUSSION}

The simultaneous choice tests showed the capability of Varroa to distinguish between bees stung to death by other bees and bees killed by freezing. Tests with a wind channel showed that the smell of the sting apparatus of worker bees is repellent for the mites. Nearly all the tested alarm pheromones were repellent in wind channel tests and in wax tube tests. In wind channel tests, the minimum effective amount of 
Table III. Ranking of alarm pheromone compounds in the different tests and amount of the pheromone compounds per worker bee. Amounts of pheromone compounds according to Collins et al (1987).

\begin{tabular}{llllll}
\hline Substance & Wax tubes (3) & Wind chanel (2) & $\begin{array}{c}\text { Amount } \\
(\mu g / \text { worker bee })\end{array}$ & $\begin{array}{c}\text { Boiling } \\
\text { point }\left({ }^{\circ} \mathrm{C}\right)\end{array}$ \\
\hline isopentyl acetate & 9 & 8 & 1 & 1.26 & 140 \\
1-octanol & 1 & 1 & 2 & 0.48 & 193 \\
2-methyl butanol & 4.5 & 3 & 3 & 0.34 & 126 \\
hexyl acetate & 8 & 7 & 4 & 0.13 & 167 \\
butyl acetate & 6 & 5 & 5 & 0.12 & 123 \\
2-nonyl acetate & 3 & 3 & 6 & 0.11 & 208 \\
2-nonanol & 4.5 & 3 & 7 & 0.05 & 192 \\
2-heptanol & 2 & 6 & 8 & 0.04 & 158 \\
1-hexanol & 7 & 9 & 9 & 0.01 & 156 \\
\hline
\end{tabular}

the tested substance is unknown. In about 80 substances tested, the attractive and repellent effects were independent of the introduced concentration. In wax tube tests, both olfaction and chemo-contact perception are involved, while in wind channel tests, only olfaction is effective. Some substances, such as eugenol, cause different responses in olfaction and chemo-contact perception (Kraus, 1989). The very high correlation between the results of both tests shows that this does not apply to the substances tested here.

IPA, the main component of alarm pheromone, was the only substance that caused no repellent effect at all. 1-octanol, the alarm pheromone compound in the second highest quantity, was the most repellent substance, in both wax tube and wind channel tests. This could not have been caused by volatility because the boiling points of 2 tested substances were lower than the boiling point of IPA. 1-octanol is effective in spite of its high boiling point and low vapour pressure. When the quantity occurring in 1 sting apparatus is injected into a bee, the mites frequently leave the abdomen of the bees within only $30 \mathrm{~s}$. This effect may be even more drastic in nature, where the surface of the bee may be contaminated with 1-octanol during a fight. However, 1-octanol does not act as an undirected trigger causing Varroa to leave a bee, since in the host changing test, the effect did not differ from the control.

Of all substances tested, 1-octanol was the most effective one, although it is not the only trigger which may cause Varroa to leave a bee. Preliminary injection tests with other compounds gave similar effects. According to Sakofski (1989), a high transfer of Varroa occurs during robbery when the mites leave the bees which are stung to death. One factor might be the decreasing temperature of the dying bees (Le Conte and Arnold, 1987; Kraus, unpubl). However, it is known from previous experiments, that Varroa rarely leave an uninjured dead bee (Kraus et al, 1986). Thus, additional factors may cause Varroa to leave bees, and contamination with alarm pheromone compounds might well be such a factor. 


\section{ACKNOWLEDGMENT}

This research was supported by DFG (Ko 400/ 10-1). I would like to thank $N$ Koeniger and $S$ Fuchs for reading and discussing the manuscript.

Résumé - Action des composants de la phéromone d'alarme de l'abeille (Apis mellifica) sur le comportement de Varroa jacobsoni. Les expériences de Sakofski (1989) sur l'importance du pillage comme facteur de transmission de grandes quantités de Varroa d'une colonie à l'autre ont montré, que lors d'un pillage, jusqu'à $40 \%$ des acariens passent de la colonie pillée à la colonie pillarde. Nous savons, par des observations personnelles et par le travail de Sakofski, que Varroa ne change que rarement d'abeille hôte. Sakofski a pu observer des varroa changer d'hôte lors d'un combat entre abeilles. Les observations suggèrent l'existence de stimuli spécifiques qui provoquent l'abandon par le Varroa de l'hôte piqué. Les expériences ont été limitées à l'action des composants de la phéromone d'alarme.

Une première série d'expériences a porté sur un test de choix simultané entre des abeilles tuées par piqûre et des abeilles tuées par le froid. Ces dernières ont été nettement préférées $\left(\chi^{2}=21,8\right.$, $P<0,001$ ), ce qui prouve l'action répulsive des composants de l'appareil venimeux vis-à-vis de Varroa (fig 1). La seconde série d'expériences a testé l'action de l'odeur de l'appareil venimeux sur Varroa dans un olfactomètre en $Y$. L'odeur s'est montrée nettement répulsive $\left(\chi^{2}=30,0\right.$, $P<0,001)$. Dans d'autres tests, 6 des 9 composants de la phéromone d'alarme se sont montrés nettement répulsifs vis-à-vis des acariens, tandis que les 3 dernières substances n'ont eu aucune action. Le 1 -octanol, $2^{\theta}$ composant en quantité de la phéromone d'alarme après l'acétate d'isopentyl (IPA), est le plus répulsif. L'IPA même n'a aucune action (tableau I). L'odeur et le goût ont pu être testés ensemble dans une $3^{\theta}$ série d'expériences où les substances étaient incorporées à de la cire. Tous les composants de la phéromone d'alarme, sauf I'IPA, ont exercé une action répulsive. Là encore, c'est le 1octanol qui a été le plus répulsif (tableau II). L'action de l'odeur d'une substance sur Varroa peut être différente de celle du goût (Kraus, 1989). La bonne corrélation des résultats des tests 2 et 3 montre que tel n'est pas le cas pour les substances testées (tableau III).

Dans la $4^{e}$ série de tests, on a injecté à des abeilles tuées par le froid $0,5 \mu \mathrm{l}$ de 1-octanol, quantité moyenne présente dans l'appareil venimeux. Les abeilles témoins ont reçu la même quantité d'eau. Deux acariens ont été placés sur l'abdomen de chaque abeille (fig 2). Au bout de $30 \mathrm{~s}$, un nombre significativement plus grand d'acariens $(P<0,01)$ avait quitté les abeilles traitées au 1-octanol. En conditions naturelles on peut s'attendre à un effet encore plus marqué, puisque au cours d'un combat le corps de l'abeille est souvent contaminé par la phéromone d'alarme.

Le 1-octanol n'est probablement pas le seul stimulus qui pousse Varroa à quitter les abeilles tuées par piqûre. D'autres composants de la phéromone d'alarme peuvent jouer un rôle mineur; un action du venin est possible; le refroidissement des abeilles mourantes pourrait bien jouer un rôle (Le Conte et Arnold, 1987; Kraus, non publié). Mais les résultats présents montrent que le 1-octanol constitue très certainement un stimulus important.

Apis mellifica / phéromone d'alarme / perception chimiosensorielle / action répulsive / Varroa jacobsoni 
Zusammenfassung - EinfluB von Bestandteilen des Alarmpheromons der Honigbiene auf das Verhalten von Varroa jacobsoni. Versuche von Sakofski (1989) bezüglich der Bedeutung von Räuberei als Faktor zur Übertragung größerer Mengen von Varroa von Volk zu Volk zeigten, daß bis zu $40 \%$ der Milben aus dem ausgeräuberten Volk auf die Räuber umsteigen. Aus eigenen Beobachtungen und der Arbeit von Sakofski ist bekannt, daß Varroa normalerweise die Wirtsbiene nur relativ selten wechselt. Bei Versuchen von Sakofski wechselten nur 5\% der Milben in 24 Stunden die Biene. Auch konnte Sakofski direkt zwischen kämptenden Bienen umsteigende Varroa beobachten. Im Falle der Räuberei muß es also Auslöser geben, die die Milben zum Umsteigen bewegen. Frühere Versuche deuteten auf eine abstoßende Wirkung des Stachelapparates hin. Es lag daher nahe, einen möglichen Zusammenhang zu untersuchen. Die Versuche wurden auf Bestandteile des Alarmpheromons beschränkt.

Als erstes wurden Simultanwahlversuche $z$ wischen abgestochenen Bienen und durch Einfrieren getöteten Bienen durchgeführt. Dabei wurden die durch Einfrieren getöteten Bienen deutlich bevorzugt. Damit ist eine abstoßende Wirkung von Bestandteilen des Stachelapparates auf Varroa gezeigt $\left(\chi^{2}=21,8\right.$; $P<0,001$ ).

In einem 2. Test wurde in einem Windkanal (Y-Rohr) die Wirkung des Geruches von Stachelapparaten auf Varroa getestet. Der Geruch wirkte deutlich abstoßend $\left(\chi^{2}=30,0 ; P=0,001\right)$. Bei einem Test von 9 Bestandteilen des Alarmpheromons wirkten $6 \quad$ der Substanzen deutlich abstoßend auf die Milben, während 3 der Substanzen keine Wirkung zeigten. Am abstoßendsten wirkte 1-Octanol, welches nach dem IPA in der zweitgrößten Menge im Stachelapparat vorliegt. IPA selbst zeigte keine Wirkung (Tabelle I).

In einem 3. Test, bei dem die Substanz in Wachs eingerührt wurde, konnten Geruch und Geschmack gemeinsam getestet werden. Hier zeigte lediglich IPA keine Wirkung. Alle anderen getesteten Alarmpheromon-Bestandteile waren deutlich abstoßend. Auch hier zeigte 1-Octanol die stärkste Wirkung (Tabelle II). Die Wirkung von Geruch und Geschmack einer Substanz auf Varroa kann unterschiedlich sein (Kraus, 1989). Die gute Korrelation der Ergebnisse von 2er und $3 e r$ Tests zeigt, daß dies bei den hier getesteten Substanzen nicht der Fall ist (Tabelle III).

In einem 4. Test wurde durch Einfrieren getöteten Bienen 0,5 $\mu$ l 1-Octanol, die nach natürlicher Menge und Wirksamkeit effektivste Substanz, injiziert. Dies entspricht der durchschnittlich in einem Stachelapparat vorliegenden Menge. Einer Kontrollbiene wurde die gleiche Menge Wasser injiziert. Auf das Abdomen der Bienen wurden jeweils 2 Milben gesetzt. Bereits nach $30 \mathrm{sec}$ hatten signifikant mehr Milben $(P<0,01)$ die mit 1-Octanol behandelten Bienen verlassen als die Kontrollbienen (Abb 2). Unter natürlichen Umständen ist ein noch stärkerer Effekt zu erwarten, da hier die kämpfenden Bienen wahrscheinlich häufig mit Alarmpheromon kontaminiert werden.

Sehr wahrscheinlich ist 1-Octanol nicht der einzige Auslöser, der Varroa dazu bewegt, abgestochene Bienen zu verlassen. Andere Bestandteile des Alarmpheromons mögen eine kleinere Rolle spielen. Ein Effekt von Stachelgiften ist möglich. Ebenso spielt wohl auch das Abkühlen der sterbenden Bienen eine Rolle (Le Conte und Arnold, 1987; Kraus, unveröff.). Sehr wahrscheinlich ist aber nach den vorliegenden Ergebnissen, daß 
1-Octanol ein wichtiger Auslöser für das Verlassen der gestochenen Bienen ist.

Apis mellifera / Alarmpheromon / abstossende Substanzen / Varroa jacobsori

\section{REFERENCES}

Collins AM, Brown MA, Rinderer TE, Harbo JR, Tucker KW (1987) Heritabilities of honey-bee alarm pheromone production. $J$ Hered 78 , 29-31

Hänel $\mathrm{H}$ (1983) Effect of JH III on the reproduction of Varroa jacobsoni. Apidologie 14, 137 142
Hoppe H, Ritter W (1988) The influence of the Nasonov pheromone on the recognition of house bees and foragers by Varroa jacobsoni. Apidologie 19, 165-172

Kraus B (1989) Effects of Chemical Compounds in the Orientation of Varroa jacobsoni. Proceeding of the European Experts' Group Meeting 1988, Udine (in press)

Kraus B, Koeniger N, Fuchs $S$ (1986) Unterscheidung zwischen Bienen verschiedenen Alters durch Varroa jacobsoni Oud. und Bevorzugung der Ammenbienen im Sommerbienenvolk. Apidologie 17, 257-266

Le Conte Y, Arnold G (1987) Influence de l'åge des abeilles (Apis mellifica $L$ ) et de la chaleur sur le comportement de Varroa jacobsoni Oud. Apidologie 18, 305-320

Sakofski F (1989) Transfer of Varroa jacobsoni by robbing. Proceeding of the European Experts' Group Meeting 1988, Udine (in press) 